\title{
PENGARUH LINGKUNGAN KERJA DAN KOMPETENSI INDIVIDU TERHADAP KINERJA PEGAWAI PADA PT. PERKEBUNAN SUMATERA UTARA
}

\author{
Agus Susanto \\ STIE IT\& B Medan Indonesia Jl. Mahoni No.16, Medan, 20235, Indonesia \\ e mail : agus_susanto@yahoo.com
}

\begin{abstract}
The purpose of this study was to determine the influence of the working environment and competence of individuals to employee performance at PT. North Sumatera Plantations. The study population was all employees of the company as much as 157 people with a sample of 43 people. Data collection techniques used were questionnaires and documentation. The data analysis technique used is multiple linear regression equation with the F test and $t$. From the analysis and discussion is obtained that the working environment and competence of individuals simultaneously and partially influenced the performance of employees at PT. North Sumatera Plantations. Employee performance variation can be explained by the working environment and the individual competence of 86.5 percent.
\end{abstract}

Keywords: Work Environment, Individual Competency and Performance Officer

\section{PENDAHULUAN}

Sumber daya manusia adalah sebagai aset paling penting yang dapat menjamin perkembangan dan kelangsungan hidup perusahaan, karena tanpa tenaga kerja yang profesional dan terampil sulit bagi perusahaan untuk mencapai tujuannya. Tujuan perusahaan dapat tercapai apabila pegawai yang terlibat dalam aktivitasnya memiliki kinerja yang baik. Kinerja pegawai merupakan hasil kerja yang dicapai seseorang dalam melaksanakan tugasnya sesuai dengan tanggungjawabnya. Kinerja pegawai dipengaruhi oleh lingkungan kerja dan kompetensi individu.

Lingkungan kerja menunjukkan segala sesuatu yang ada di sekitar pekerja, yang dapat mempengaruhi dirinya dalam menjalankan tugas yang dibebankan padanya. Faktor-faktor yang mempengaruhi lingkungan kerja adalah pewarnaan, penerangan, udara, pemasangan kipas angin atau air conditioner, kebisingan, ruang gerak, keamanan dan kebersihan. Ruang kerja yang menggunakan cat berwarna cerah dan tempat kerja yang bersih dapat mendorong semangat pegawai dalam menyelesaikan tugas-tugasnya, sehingga kinerjanya meningkat. Kebisingan lingkungan kerja disebabkan oleh musik, sehingga mengganggu konsentrasi pegawai dalam menyelesaikan tugas-tugasnya dan hal ini mengakibatkan tugas-tugas yang dibebankan oleh atasan sulit diselesaikan. Selain itu, pegawai lebih senang dan nyaman bekerja apabila fasilitas kerja disusun rapi, ruangan memiliki ventilasi yang cukup dan peralatan kerja memadai serta modern. Jika lingkungan kerja menyenangkan, maka pegawai lebih konsentrasi dalam mengerjakan tugas-tugasnya, sehingga kinerja yang distandarkan dapat tercapai.

Kompetensi sebagai karakteristik dasar seseorang yang memungkinkan pegawai mengeluarkan kinerja superior dalam pekerjaannya. Kompetensi individu mencakup kompetensi teknis, kompetensi konseptual dan kompetensi untuk hidup. Kompentesi teknis berkaitan dengan pengetahuan dan keahlian untk mencapai hasil- 
hasil yang telah disepakati, kemampuan memikirkan masalah dan mencari alternatif penyelesaian masalah. Kemampuan konseptual berkaitan dengan kemampuan melihat garis besar masalah, menguji berbagai pengandaian dan mengubah persepsi. Kemampuan untuk hidup berhubungan dengan kemampuan yang efektif dengan orang lain, termasuk kemampuan mendengar, berkomunikasi, menciptakan kesepakatan, mencari solusi alternatif, kemampuan melihat dan bekerja secara efektif dalam menyelesaikan tugas-tugasnya.

Perusahaan terus mengembangkan potensi pegawai yang memiliki kompetensi. Kompetensi yang dimiliki oleh pegawai harus selalu dikembangkan guna mencapai visi dan misi organisasi. Kompetensi berkaitan dengan motivasi, di mana apabila karyawan memiliki kompetensi, tidak mendapat dukungan dari berbagai pihak maka kompetensi tersebut tidak dapat berjalan optimal, sehingga mengakibatkan penurunan kinerja. Dengan demikian, jika kompetensi individu semakin baik, maka tugas-tugas yang dibebānkan kepada pegawai dapat diselesaikan dengan baik, sehingga kinerja pegawai meningkat.

Presilia dan Octavia (2008) meneliti pengaruh lingkungan kerja, karakteristik individu dan motivasi terhadap kinerja pegawai. Hasil penelitiannya menyimpulkan bahwa lingkungan kerja berpengaruh signifikan secara parsial terhadap kinerja pegawai. Rizal, dkk., (2013), meneliti pengaruh faktor kompetensi terhadap kinerja individu di Perusahaan Agro Industri yang Go Public di Bursa Efek Indonesia. Hasil penelitiannya menyatakan "kompetensi berpengaruh positif dan signifikan terhadap kinerja karyawan di perusahaan Agro Industri yang go public di Bursa Efek Indonesia". Febriyanti dkk., (2013), meneliti pengaruh pelatihan terhadap kompetensi dan kinerja karyawan pada PT. Perkebunan Nusantara X (Persero) PG. Lestari Nganjuk. Hasil penelitiannya menyimpulkan bahwa "variabel kompetensi individu berpengaruh signifikan terhadap kinerja karyawan PT. Perkebunan Nusantara $X$ (Persero) PG. Lestari Nganjuk"'. Linawati dan Suhaji (2012), meneliti pengaruh motivasi, kompetensi, kepemimpinan dan fingkungan kerja terhadap kinerja karyawan pada PT. Herculon Carpet Semarang. Hasil penelitiannya menyimpulkan bahwa "kompetensi dan lingkungan kerja berpengaruh terhadap kinerja karyawan pada PT. Herculon Carpet Semarang."

PT. Perkebunan Sumatera Utara merupakan salah satu perusahaan yang bergerak di bidang perkebunan karet dan kelapa sawit. Untuk menjaga lingkungan kerja agar lebih menyenangkan bagi pegawai, perusahaan memasang AC atau kipas angin di ruang kerja dan dilengkapi alat penerangan yang cukup, pegawai dilarang ribut pada jam kerja, menempatkan sebagian pegawai sebagai petugas kebersihan, menata ruang kerja serta mendesain halaman kantor sebagai tempat parkir dan taman. Untuk menjaga harta kekayaan perusahaan dan pribadi pegawai, perusahaan memiliki petugas keamanan. Berdasarkan uraian di atas dilakukan kajian bagaimana pengaruh lingkungan kerja dan kompetensi individu terhadap kinerja pegawai pada PT. Perkebunan Sumatera Utara.

\section{TINJAUAN PUSTAKA}

\section{A. Pengertian Lingkungan Kerja}

Lingkungan kerja mempengaruhi kelancaran pelaksanaan tugas-tugas yang dibebankan kepada karyawan. Oleh karena itu, perusahaan harus mampu 
menciptakan lingkungan kerja yang menyenangkan bagi karyawan. Lingkungan kerja termasuk faktor-faktor di luar manusia baik fisik maupun non fisik dalam sesuatu organisasi. Lingkungan kerja yang baik sangat bermanfaat bagi kelangsungan hidup organisasi, karena tidak jarang terjadi suatu organisasi gulung tikar karena adanya lingkungan kerja yang tidak kondusif. Lingkungan kerja yang kondusif diciptakan oleh pegawai dan organisasi akan mendorong efektivitas dari organisasi tersebut. Suatu perusahaan dalam melaksanakan aktivitasnya selalu berhadapan dengan manusia sebagai sumber daya manusia yang dinamis dan memiliki kemampuan untuk terus berkembang. Salah satu faktornya adalah lingkungan kerja. Oleh karena itu, pimpinan harus memahami lingkungan tempat berlangsungnya usahanya dan diarahkan pada tujuan yang ingin dicapai, dan mampu mengubah lingkungan itu untuk menciptakan suasana yang lebih tepat bagi usaha dan menciptakan kondisi yang menyenangkan bagi karyawan. Menurut Sofyan (2013:19), "lingkungan kerja adalah segala sesuatu yang berada Udi Isekitar para pekerja dan yang dapat mempengaruhi dirinya dalam menjalankan tugas-tugas yang diembankan kepada pegawai". Menurut Tohardi (2006:142), "lingkungan kerja adalah keseluruhan atau setiap aspek dari gejala fisik dan sosial-kultural yang mengelilingi atau mempengaruhi individu".

Berdasarkan definisi tersebut dapat dinyatakan lingkungan kerja adalah segala sesuatu yang ada di sekitar para pekerja yang dapat mempengaruhi dirinya dalam menjalankan tugas-tugas yang dibebankan. Masalah lingkungan kerja dalam organisasi sangatlah penting, maka diperlukan adanya pengaturan maupun penataan faktor-faktor lingkungan fisik penyelenggaraan aktivitas organisasi.

\section{B. Faktor-faktor yang Mempengaruhi Lingkungan Kerja}

Lingkungan kerja merupakan segala sesuatu yang ada di sekitar para pekerja yang dapat mempengaruhi dirinya dalam melaksanakan tugas-tugasnya. Menurut Presilia dan Octavia (2010:5-6), faktor-faktor yang mempengaruhi lingkungan kerja adalah:

\section{Illumination (penerangan)}

Cahaya atau penerangan sangat besar manfaatnya bagi para pegawai guna mendapat keselamatan dan kelancaran kerja. Dengan penerangan yang baik para pegawai akan dapat bekerja dengan cermat dan teliti sehingga hasil kerjanya mempunyai kualitas yang memuaskan. Cahaya yang kurang jelas mengakibatkan penglihatan kurang jelas, sehingga pekerjaan menjadi lambat, banyak mengalami kesalahan, dan pada akhirnya menyebabkan kurang efisien dalam melaksankan pekerjaan, sehingga tujuan dari badan usaha sulit dicapai.

2. Noise (kebisingan)

Bising dapat didefinisikan sebagai bunyi yang tidak disukai. Suara bising adalah suatu hal yang dihindari oleh siapapun, lebih-lebih dalam melaksanakan suatu pekerjaan, karena konsentrasi pegawai akan dapat terganggu. Dengan terganggunya konsentrasi ini maka pekerjaan yang dilakukkan akan banyak timbul kesalahan ataupun kerusakan sehingga akan menimbulkan kerugian.

3. Temperature (temperatur).

Bekerja pada suhu yang panas atau dingin dapat menimbulkan penurunan kinerja. Secara umum, kondisi yang panas dan lembab cenderung meningkatkan 
penggunaan tenaga fisik yang lebih berat, sehingga pekerja akan merasa sangat letih dan kinerjanya akan menurun.

4. Pollution (pencemaran)

Pencemaran dapat disebabkan karena tingkat pemakaian bahan kimia di tempat kerja dan keanekaragaman zat yang dipakai pada berbagai bagian yang ada di tempat kerja, dan pekerjaan yang menghasilkan perabot. Bahan baku-bahan baku bangunan yang digunakan di beberapa kantor dapat dipastikan mengandung bahan kimia yang beracun. Situasi tersebut akan sangat berbahaya jika di tempat tersebut tidak terdapat ventilasi yang memadai.

5. Aesthetic Factors (faktor keindahan).

Faktor keindahan meliputi: musik, warna dan bau-bauan. Musik, warna dan baubauan yang menyenangkan dapat meningkatkan kepuasan kerja dalam melaksankan pekerjaanya.

6. Feeling of privacy (privasi yang dirasakan)

Privasi dari pekerja dapat dirasakan dari desain ruang kerja. Ada ruang kerja yang didesain untuk seorang pekerja atau didesain untuk beberapa orang.

7. Sense of status and imporance (desain ruang yang terbuka)

Para pegawai tingkat bawah senang dengan desain ruang yang terbuka karena memberi kesempatan kepada pegawai untuk berkomunikasi secara informal.

\section{Pengertian Kompetensi Individu}

Sutrisno (2009:221), mengemukakan bahwa "kompetensi adalah suatu yang mendasari karakteristik dari suatu individu yang dihubungkan dengan hasil yang diperoleh dalam suatu pekerjaan". Mangkunegara (2005:113), "kompetensi individu adalah faktor mendasar yang dimiliki seseorang yang mempunyai kemampuan lebih, yang membuatnya berbeda dengan seorang yang mempunyai kemampuan rata-rata atau biasa saja". Menurut Mathis dan Jackson (2002:238), "kompetensi adalah karakteristik dasar yang dapat dihubungkan dengan peningkatan kinerja individu atau tim".

Berdasarkan defenisi di atas, dapat dikatakan bahwa kompetensi individu merupakan karakter sikap dan perilaku, atau kemampuan individual yang relatif bersifat stabil, ketika menghadapi suatu situasi di tempat kerja yang terbentuk dari sinergi antar watak, konsep diri, motivasi internal, serta kapasitas pengetahuan. Pemikiran-pemikiran baru tentang manajer kinerja dan karier pegawai diperlukan perubahan sikap dari manajer dan pegawai dalam mengembangkan kompetensi untuk membangun perusahaan yang unggul di masa depan. Oleh karena itu, pengambil keputusan di bidang sumber daya manusia perlu menyempurnakan halhal yang berkaitan dengan kualifikasi atau persyaratan kemampuan seseorang untuk mengemban tugas pekerjaan tertentu, dengan tidak menggunakan istilah kecakapan lagi malainkan kompetensi. Pergeseran paradigma dari konsep kecakapan menjadi kompetensi, secara perlahan tetapi pasti telah menimbulkan implikasi strategis yang sangat positif bagi kegiatan perencanaan dan pengelolaan sumber daya manusia di lingkup apapun dalam kegiatan bisnis. Menurut Mangkunegara (2005:112), kompetensi tersebut mencakup: 
a. Kompetensi teknis: pengetahuan dan keahlian untuk mencapai hasil-hasil yang telah disepakati, kemampuan untuk memikirkan persoalan dan mencari alternatifalternatif baru.

b. Kompetensi konseptual: kemampuan untuk melihat gambar besar, untuk menguji berbagai pengandaian dan pengubah perspektif.

c. Kompetensi untuk hidup dalam saling ketergantungan kemampuan secara efektif dengan orang lain, termasuk kemampuan untuk mendengar, berkomunikasi, mendapat alternatif ketiga, menciptakan kesepakatan menang-menang, dan berusaha mencapai solusi alternatif ketiga, kemampuan untuk melihat dan beroperasi secara efektif dalam organisasi atau sistem yang utuh.

Kompetensi sebagai penguasaan terhadap suatu tugas, keterampilan, sikap dan apresiasi yang diperlukan untuk menunjang kelancaran pelaksanaan tugas yang dibebankan kepada karyawan. Kompetensi yang harus dikuasai oleh karyawan harus dinyatakan sedemikian rupa agar dapat dinilai, sebagai wujud hasil pelaksanaan tugas yang mengacu pada pengalaman langsung. Penilaian terhadap pencapaian kompetensi perlu dilakukan secara objektif, berdasarkan kinerja karyawan yang ada di dalam organisasi, dengan bukti penguasaan mereka terhadap pengetahuan, keterampilan, nilai dan sikap sebagai hasil belajar.

Menurut Sutrisno (2009:225), karakteristik kompetensi individu terdapat lima aspek, yakni:

1. Motives (motif) adalah sesuatu di mana seseorang secara konsisten berpikir, sehingga ia melakukan tindakan. Misalnya orang memiliki motivasi berprestasi secara konsisten mengembangkan tujuan-tujuan yang memberi tantangan pada dirinya dan bertanggungjawab penuh untuk mencapai tujuan tersebut serta mengharapkan feedback untuk memperbaiki dirinya.

2. Traits (karakter pribadi) adalah watak yang membuat orang untuk berperilkau atau bagaimana seseorang merespon sesuatu dengan cara tertentu. Misalnya, percaya diri, kontrol diri, dan ketabahan.

3. Self concept (konsep diri) adalah sikap dan nilai-nilai yang dimiliki seseorang. Sikap dan nilai diukur melalui tes kepada responden untuk mengetahui bagaimana nilai yang dimiliki seseorang, apa yang menarik seseorang melakukan sesuatu.

4. Knowledge (pengetahuan yang dimiliki) adalah informasi yang dimiliki seseorang untuk bidang tertentu. Pengetahuan merupakan komptensi yang kompleks.

5. Skill (keterampilan) adalah kemampuan untuk melaksanakan suatu tugas tertentu baik secara fisik maupun mental.

Komponen kompetensi yang motif, karakter pribadi, dan konsep diri dapat meramalkan suatu perilaku tertentu yang pada akhirnya akan muncul sebagai prestasi kerja. Kompetensi juga selalu melibatkan intensi atau kesengajaan yang mendorong sejumlah motif atau karakter pribadi untuk melakukan suatu aksi menuju terbentuknya suatu hasil.

\section{Manfaat Kompetensi Individu}

Menurut Sutrisno (2009:227-228), konsep kompetensi semakin populer dan sudah banyak digunakan perusahaan besar dengan berbagai manfaat, yaitu:

1. Memperjelas standar kerja dan harapan yang ingin dicapai. Dalam hal ini, model kompetensi akan mampu menjawab dua pertanyaan mendasar: keterampilan, 
kemampuan, dan karakteristik apa saja yang dibutuhkan dalam pekerjaan, dan perilaku apa saja yang berpengaruh langsung dengan prestasi kerja. Kedua hal tersebut akan banyak membantu dalam mengurangi pengambilan keputusan secara subjektif dalam bidang sumber daya manusia.

2. Alat seleksi karyawan. Penggunaan kompetensi standar sebagai alat seleksi dapat membantu organisasi untuk memilih calon karyawan yang terbaik. Dengan kejelasan terhadap perilaku efektif yang diharapkan dari karyawan, perusahaan dapat mengarahkan pada saat yang selektif, serta mengurangi biaya rekruitmen yang tidak perlu. Caranya dengan mengembangkan suatu perilaku yang dibutuhkan untuk setiap fungsi jabatan serta memfokuskan wawancara seleksi pada perilaku yang dicari.

3. Memaksimalkan produktivitas. Tuntutan untuk menjadikan suatu organisasi ramping mengharuskan perusahaan untuk mencari karyawan yang bisa dikembangkan secara terarah untuk menutupi kesenjangan dalam keterampilan, sehingga mampu untuk dimobilisasi secara vertikal maupun horizontal.

4. Dasar untuk pengembangan sistem remunerasi- Model kompetensi dapat digunakan untuk mengembangkan sistem remunerasi (imbalan) yang dianggap lebih adil. Kebijakan remunerasi akan lebih terarah dan transparan dengan mengaitkan sebanyak mungkin keputusan dengan suatu set perilaku yang diharapkan yang ditampilkan seorang karyawan.

5. Memudahkan adaptasi terhadap perubahan. Dalam era perubahan yang sangat cepat, sifat dari suatu pekerjaan sangat cepat berubah dan kebutuhan akan kemampuan baru terus meningkat. Model kompetensi memberikan sarana untuk menetapkan keterampilan apa saja yang dibutuhkan untuk memenuhi kebutuhan yang selalu berubah ini.

6. Menyelaraskan perilaku kerja dengan nilai-nilai organisasi. Model kompetensi merupakan cara yang paling mudah untuk mengkomunikasikan nilai-nilai dan hal-hal apa saja yang harus menjadi fokus dalam unjuk kerja pegawai.

\section{E. Faktor-faktor yang Mempengaruhi Kompetensi Individu}

Kompetensi sebagai pengetahuan, keterampilan dan kemampuan yang dikuasai oleh seseorang yang telah menjadi bagian dari dirinya, sehingga ia dapat melakukan perilaku-perilaku yang mendukung pelaksanaan tugas-tugasnya. Menurut Simanjuntak (2005:10), kompetensi setiap orang dipengaruhi oleh beberapa faktor, berikut:

1. Kemampuan kerja. Kemampuan kerja setiap orang dipengaruhi oleh kebugaran fisik dan kesehatan pegawai yang bersangkutan, pendidikan, pelatihan, dan pengalaman kerjanya. Kebugaran fisik membuat orang mampu dan tahan bekerja keras dan lama. Sebaliknya, pekerja yang kekurangan gizi akan cepat lemah dan lelah, serta tidak mampu melakukan pekerjaan berat. Demikian juga gangguan kejiwaan akibat rasa frustasi dan masalah sosial ekonomi, hal ini membuat tenaga kerja tidak konsisten dan tidak terkonsentrasi melakukan pekerjaan.

2. Pendidikan dan pelatihan. Pendidikan dan pelatihan merupakan bagian dari investasi sumber daya manusia. Semakin lama waktu yang digunakan untuk pendidikan dan pelatihan semakin tinggi kemampuan dan kompetensinya melakukan pekerjaan, dan dengan demikian semakin tinggi kinerjanya. 
3. Pengalaman kerja. Pengalaman kerja dapat memperdalam dan memperluas kemampuan kerja. Semakin sering seseorang melakukan pekerjaan yang sama, semakin terampil dan semakin cepat dia menyelesaikan pekerjaan tersebut. Semakin banyak macam pekerjaan yang dilakukan seseorang, pengalaman kerjanya semakin luas, dan memungkinkan peningkatan kinerja.

4. Motivasi. Motivasi adalah semua kekuatan yang ada dalam diri seseorang yang memberi daya, memberi arah dan memelihara tingkah laku. Berbagai usaha dilakukan seseorang untuk memenuhi keinginan dan kebutuhannya, namun agar keinginan dan kebutuhannya terpenuhi tidaklah mudah didapatkan. Dalam memenuhi kebutuhan dan keinginannya, seseorang akan berperilaku sesuai dengan dorongan yang dimiliki dan apa yang mendasari perilakunya.

5. Etos kerja. Etos kerja merupakan sikap dasar seseorang yang membangun perilaku kerja berlandaskan pada kesadaran mental, keyakinan dengan disertai komitmen sepenuhnya kepada kegiatan kerja yang dilakukannya secara utuh. Sikap dan pandangan tersebut akan memberikan penilaian terhadap kerja dan sikap dalam melaksanakan pekerjaan. Seseorang yang melihat tugas sebagai beban dan keterpaksaan untuk memperoleh uang, akan mempunyai kinerja yang rendah. Sebaliknya, seseorang yang memandang pekerjaan sebagai kebutuhan, pengabdian, tantangan, akan menghasilkan kinerja yang tinggi.

\section{F. Pengertian dan Ukuran Kinerja Pegawai}

Kinerja sumber daya manusia merupakan istilah yang berasal dari kata job performance atau actual performance (prestasi kerja atau prestasi sesungguhnya dicapai seseorang). Menurut Hasibuan (2005:94), "kinerja adalah suatu hasil kerja yang dicapai seseorang dalam melaksanakan tugas-tugas yang dibebankan kepadanya yang didasarkan atas kecakapan, pengalaman dan kesungguhan serta waktu". Mangkunegara (2005:9) mengatakan bahwa "kinerja adalah merupakan hasil kerja secara kualitas dan kuantitas yang dicāpai oleh seseorang dalam melaksanakan fungsinya sesuai dengan tanggung jawab yang diberikan kepadanya. Berdasarkan pengertian di atas, dapat disimpulkan bahwa kinerja pegawai sebagai kemampuan pegawai dalam melakukan sesuatu dengan keahlian tertentu. Inti dari manajemen prestasi kerja menunjukkan upaya karyawan harus memiliki tujuan yang jelas. Riani (2011:99), menyatakan ukuran-ukuran dari kinerja karyawan adalah:

1. Quantity of work (kuantitas kerja): jumlah kerja yang dilakukan dalam suatu periode yang ditentukan.

2. Quality of work (kualitas kerja): kualitas kerja yang dicapai berdasarkan syaratsyarat kesesuaian dan kesiapan.

3. Job knowledge (pengetahuan): luasnya pengetahuan mengenai pekerjaan dan keterampilannya.

4. Creativeness (kreativitas): keaslian gagasan-gagasan yang dimunculkan dan tindakan-tindakan untuk menyelesaikan persoalan-persoalan yang timbul.

5. Coorporate (kerja sama): kesadaran untuk bekerja sama dengan orang lain atau sesama anggota organisasi.

6. Dependability (dapat dipercaya): kesadaran untuk dapat dipercaya dalam hal kehadiran dan penyelesaian pekerjaan. 
7. Initiative (inisiatif), semangat untuk melaksanakan tugas-tugas baru dan dalam memperbesar tanggungjawabnya.

8. Personal quality (kualitas pribadi): menyangkut kepribadian, kepemimpinan, keramahtamahan dan integritas pribadi.

Ada dua aspek yang terkait dengan hal ini, pertama, manajer harus menilai karyawan berdasarkan bagaimana orang tersebut melakukan tugas-tugasnya sesuai pencapaian standar tertentu yang diinginkan. Kedua, tujuan dan standar kinerja harus sesuai dengan tujuan strategis organisasi. Menurut Mangkunegara (2005:28), individu yang memiliki motivasi berprestasi tinggi untuk mencapai kinerja dapat dibedakan dalam ciri-ciri berikut:

1. Individu yang senang bekerja dan menghadapi tantangan yang moderat

2. Individu yang memperoleh sedikit kepuasan jika pekerjaannya sangat mudah dan jika terlalu sulit cenderung kecewa

3. Individu yang senang memperoleh ümpan balik yang konkret mengenai keberhasilan pekerjaannya

4. Individu yang cenderung tidak menyenangi tugas tersebut jika tidak mencapai prestasi sesuai dengan yang diinginkan

5. Individu senang bertanggungjawab secara personal atas tugas yang diberikan

6. Individu yang puas dengan hasil bila pekerjaan dilakukan sendiri

7. Individu yang kurang istirahat, cenderung inovatif dan banyak bepergian

8. Individu yang selalu mencari kemungkinan pekerjaan yang lebih menantang, meninggalkan sesuatu yang lama dan menjadi rutinitas serta berusaha untuk menemukan sesuatu yang baru.

\section{G. Faktor-faktor yang Mempengaruhi Kinerja Pegawai}

Menurut Mangkunegara (2005:10), faktor yang mempengarui pencapaian kinerja adalah faktor kemampuan (ability) dan faktor motivasi (motivation).

1. Faktor kemampuan (ability). Secara Ipsikologis, kemampuan terdiri dari kemampuan potensi (IQ) dan kemampuan reality (knowledge + skill). Artinya, pimpinan dan karyawan yang memiliki kemampuan potensi di atas rata-rata (IQ 110 - 120) apalagi IQ superior, very superior, gifted dan genius dengan pendidikan yang memadai untuk jabatannya, dan terampil dalam mengerjakan pekerjaan sehari-hari, maka akan lebih mudah mencapai kinerja maksimal.

2. Faktor motivasi (motivation). Motivasi diartikan suatu sikap (attitude) pimpinan dan karyawan terhadap situasi kerja (situation) di lingkungan organisasinya. Mereka yang bersikap positif terhadap situasi kerjanya akan menunjukkan motivasi kerja yang tinggi dan sebaliknya, jika mereka bersikap negatif terhadap situasi kerjanya akan menunjukkan motivasi kerja yang rendah. Situasi kerja yang dimaksud mencakup antara lain: hubungan kerja antara atasan dengan bawahan maupun antar rekan kerja, fasilitas kerja, iklim kerja, kebijakan pimpinan, pola kepemimpinan kerja dan kondisi kerja.

Menurut Steers dalam Sutrisno (2009:165-166), faktor-faktor yang mempengaruhi kinerja karyawan adalah:

1. Faktor individu, yang dimaksud adalah: 

a. Usaha (effort), menunjukkan sejumlah sinergi fisik dan mental yang digunakan dalam menyelenggarakan gerakan tugas.
b. Abilities, yaitu sifat personal yang diperlukan untuk melaksanakan suatu tugas.
c. Task perception, yaitu segala perilaku dan aktivitas yang dirasa perlu oleh individu untuk menyelesaikan suatu pekerjaan.

2. Faktor lingkungan

Faktor-faktor lingkungan yang mempengaruhi kinerja adalah kondisi fisik, peralatan, waktu, material, pendidikan, supervisi, desain organisasi, dan pelatihan. Faktor lingkungan tidak langsung menentukan kinerja karyawan, tetapi mempengaruhi faktor-faktor individu. Dengan demikian, kinerja karyawan merupakan hasil dari gabungan variabel individual dan variabel fisik dan pekerjaan serta variabel organisasi dan sosial.

\section{H. Kerangka Berpikir}

Kerangka berpikir dalam penelitian disajikan pada gambar berikut:

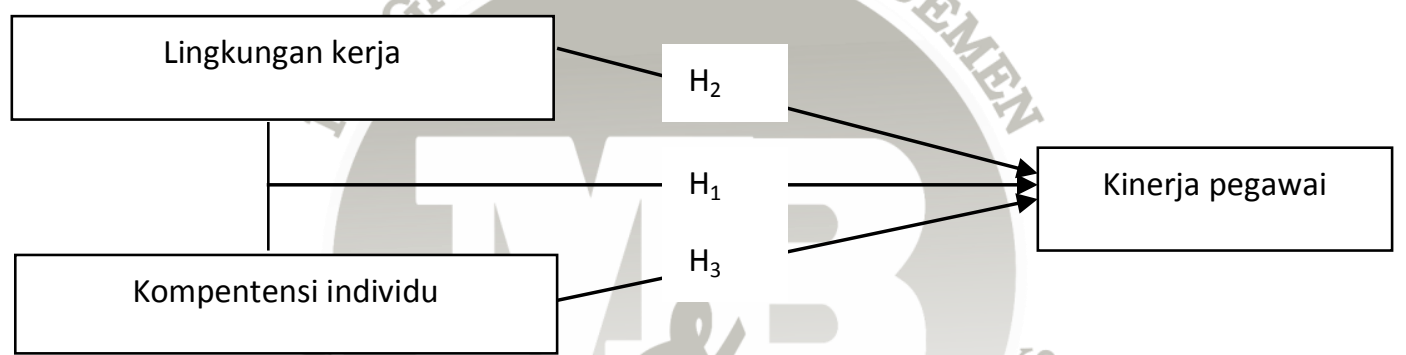

Gambar 1. Kerangka Berpikir

Lingkungan kerja merupakan keseluruhan sarana dan prasarana yang ada disekitar karyawan yang sedang melakukan pekerjaan yang dapat mempengaruhi pelaksanaan pekerjaan tersebut. Menurut Sofyan (2013:19), "lingkungan kerja sangat berpengaruh terhadap pekerjaan A yang Tlilakukan pegawai, sehingga setiap perusahaan haruslah mengusahakan lingkungan kerja yang sedemikian rupa agar memberikan pengaruh positif terhadap pekerjaan yang dilakukan pegawai". Menurut Bridger dalam Astuti (2009), mengartikan ergonomi sebagai ilmu yang mempelajari interaksi antara manusia dan mesin serta faktor-faktor yang mempengaruhinya. Ergonomi merupakan aplikasi ilmu untuk menyesuaikan pekerjaan, lingkungan kerja dan pengorganisasian pekerjaan dengan pekerjaannya dengan menekankan pada desain peralan, pekerjaan dan lingkungan tersebut. Dengan demikian, ergonomi merupakan multidisiplin ilmu untuk menyesuaikan tempat kerja dan semua aspek fisiologisnya terhadap pekerjaan sesuai dengan kemampuan dan keterbatasan manusian untuk meningkatkan kinerja dan kualitas degnan mengurangi risiko di tempat kerja.

Dalam penerapannya secara lebih luas, ergonomi juga mempertimbangkan aspek pekerjaan yang dilakukan dan tuntutannya terhadap pekerja, peralatan yang digunakan, informasi yang digunakan, lingkungan fisik (temperatur, kelembaban, pencahayaan, kebisingan, getaran dan lain-lain), serta lingkungan sosial seperti kerja tim dan dukungan manajemen. Untuk menciptakan suatu lingkungan kerja yang aman dan nyaman perlu diperhatikan masing-masing komponen yang terlibat dalam ergonomi yaitu manusia, mesin atau peralatan kerja, dan lingkungan kerja. Dalam 
ergonomi manusia merupakan komponen utama yang harus diperhatikan karena manusia yang memegang kendali dalam pekerjaannya, sehingga pekerjaan harus disesuaikan dengan karakteristik manusia. Ergonomi melibatkan berbagai disiplin ilmu untuk menyesuaikan pekerjaan dan karakteristik manusia yang dipengaruhi oleh aspek fisik dan aspek psikologis seperti kemampuan mental, kepribadian, pengetahuan dan pengalaman.

Menurut Linawati dan Suhaji (2012), hal pertama yang harus diusahakan untuk memperbaiki kinerja karyawan adalah menjamin agar karyawan dapat melaksanakan tugasnya dalam keadaan yang memenuhi syarat, sehingga mereka dapat melaksanakan tugasnya tanpa mengalami ketegangan-ketegangan, atau dengan kata lain perusahaan harus menyediakan lingkungan kerja yang baik bagi karyawannya". Dari uraian tersebut, terlihat bahwa lingkungan kerja berpengaruh positif terhadap kinerja karyawan. Hal ini dapat terwujud bila lingkungan kerja kondusif dan menyenangkan, sehingga karyawan daläm/mengerjakan tugas-tugasnya lebih berkonsentrasi, dan pada akhirnya tugas-tugasnya dapat diselesaikan dengan baik.

Kompetensi yang terdiri dari sejumlah perilaku knci yang dibutuhkan untuk melaksanakan peran tertentu untuk menghasilkan kinerja yang memuaskan. Perilaku ini biasanya ditunjukkan secara konsisten oleh para pekerja yang melakukan aktivitas kerja. Menurut Sutrisno (2009:221), kompetensi sebagai karakteristik yang mendasari sesorang dan berkaitan dengan efektivitas kinerja individu dalam pekerjaannya. Dari hal tersebut mengandung makna kompetensi adalah bagian kepribadian yang mendalam dan melekat kepada seseorang serta perilaku yang dapat diprediksi pada berbagai keadaan dan tugas pekerjaan. Pegawai yang berkualitas memiliki kompetensi (knowledge, skill, abilities, dan experience) yang memadai. Menurut Dharma dalam Febrianti dkk., (2013), kompetensi mengacu pada dimensi perilaku dari sebuah peran perilaku yang diperlukan seseorang untuk dapat melaksanakan pekerjaannya secara memuaskan. Kompetensi mencakup karakteristik perilaku yang dapat menunjukkan perbedaan antara mereka yang berkinerja tinggi yang dalam konteks ini menyangkut prestasi.

Hasil penelitian Shin dalam jurnal Rizal, dkk., (2013) menyatakan "faktor kompetensi individu memiliki pengaruh positif untuk meningkatkan kinerja karyawan. Dalam hal ini faktor utama yang mempengaruhi kompetensi adalah komitmen, pemikiran konseptual dan operasional". Dengan demikian, jika kompetensi individu semakin tinggi, maka tugas-tugas yang dibebankan oleh atasan kepada bawahan dapat dikerjakan dengan baik, sehingga kinerja karyawan meningkat. Berdasarkan uraian tersebut di atas, dapat disimpulkan bahwa lingkungan kerja yang kondusif dan kompetensi individu berpengaruh terhadap kinerja karyawan.

\section{METODE PENELITIAN}

\section{A. Populasi dan Sampel}

Populasi penelitian adalah seluruh pegawai PT. Perkebunan Sumatera Utara sebanyak 157 orang. Sampel dalam dari sub bagian pengadaan dan pemasaran sebanyak 43 orang. Teknik penentuan sampel adalah purposive sampling, yaitu pengambilan sampel dengan pertimbangan tertentu untuk mendapatkan hasil analisis yang lebih akurat. 


\section{B. Operasionalisasi Variabel}

Definisi operasional variabel dalam penelitian ini adalah:

1. Variabel bebas $(X)$ terdiri dari:

a. Lingkungan kerja $\left(X_{1}\right)$ adalah segala sesuatu yang ada di sekitar pekerja, yang dapat mempengaruhi dirinya dalam menjalankan tugas-tugasnya. Indikator pengukurannya adalah penerangan, kebisingan, temperatur/suhu udara, pencemaran, keindahan ruangan (penataan fasilitas kerja), privasi yang dirasakan atau dekorasi ruangan, desain ruang yang terbuka (taman dan tempat parkir), hubungan pegawai dengan atasan maupun hubungan sesama rekan kerja.

b. Kompetensi individu $\left(\mathrm{X}_{2}\right)$ adalah suatu yang mendasari karakteristik pegawai yang dihubungkan dengan hasil kerjanya. Indikator pengukurannya adalah pengetahuan, pemahaman, kemampuan kerja, nilai, sikap, minat, pendidikan dan latihan, pengalaman kerja, motivasi dan etos kerja.

2. Variabel terikat adalah kinerja pegawai (Y), yaitu hasil kerja secara kualitas dan kuantitas yang dicapai seseorang pegawai dalam melaksanakan tugasnya sesuai dengan tanggung jawab yang diberikan kepadanya. Indikator pengukurannya adalah kuantitas kerja, kualitas kerja, pengetahuan, kreativitas, kerja sama, dipercaya, inisiatif dan kualitas pribadi.

Skala pengukuran variabel yang digunakan adalah skala Likert.

\section{Teknik Pengumpulan Data}

Teknik pengumpulan data yang digunakan adalah: kuesioner dibagikan kepada responden untuk mengetahui pendapat responden mengenai variabel penelitian. Teknik dokumentasi, dilakukan dengan mengumpulkan data yang sudah diolah sebelumnya dari objek penelitian berupa data pegawai dan kinerja pegawai pada PT. Perkebunan Sumatera Utara tahun 2010-2013.

\section{Teknik Analisis Data}

\section{Uji Validitas dan Reliabilitas}

Dalam hal ini, teknik korelasi digunakan untuk menentukan validitas item. Selanjutnya dalam memberikan interpretasi terhadap koefisien korelasi, dimana Menurut Sugiyono (2008:188), syarat minimum dianggap memenuhi syarat kalau nilai $r=0,30$ ". Jadi kalau nilai korelasi antara butir dengan skor total kurang dari 0,30, maka butir dalam isntrumen tersebut dinyatakan tidak valid. Pengujian reliabilitas dengan internal consistency, dilakukan dengan cara mencoba instrumen sekali saja, kemudian dianalisis dengan teknik tertentu". Pengujian reliabilitas instrumen dilakukan dengan teknik belah dua dari Spearmen Brown. Kriteria suatu variabel dikatakan reliabel atau tidak, adalah: $\propto \geq 0,50$ artinya instrumen reliabel dan $\propto<0,50$ artinya instrumen tidak reliabel.

\section{Persamaan Regresi Linear}

Teknik analisis yang digunakan adalah persamaan regresi linear berganda dengan rumus: $Y=a+b_{1} X_{1}+b_{2} X_{2}+e i$

Dimana:

$$
\begin{aligned}
& \mathrm{Y}=\text { Kinerja pegawai } \\
& \mathrm{X}_{1}=\text { Lingkungan kerja } \\
& \mathrm{X}_{2}=\text { Kompetensi individu }
\end{aligned}
$$


$b_{i} \quad=$ Koefisien variabel bebas

a $=$ Konstanta, dan

ei $=$ Tingkat kesalahan estimasi.

digunakan uji $\mathrm{F}$ dan $\mathrm{t}$. Asumsi model regresi linier bergnda adalah: Uji Normalitas, Uji multikolinieritas dan Heteroskedastisitas

\section{HASIL DAN PEMBAHASAN}

\section{A. Lingkungan Kerja}

Lingkungan kerja menunjukkan segala sesuatu yang ada di sekitar pegawai yang mempengaruhi dirinya dalam menjalankan tugas-tugasnya. Lingkungan kerja yang kondusif dan menyenangkan dapat meningkatkan konsentrasi kerja pegawai dan mengurangi kebosanan kerja, sehingga tugas-tugasnya dapat diselesaikan dengan baik. Faktor-faktor yang mempengaruhi lingkungan kerja pada PT. Perkebunan Sumatera Utara adalah: (1) Penerangan, (2) Kebisingan, (3) Temperatur atau suhu udara, (4) Pencemaran, (5) Keindahan ruangan (penataan fasilitas kerja), (6) Privasi yang dirasakan atau dekorasi ruangan, (7) Desain ruang yang terbuka (taman dan tempat parkir), (8) Hubungan pegawai dengan atasan maupun hubungan sesama rekan kerja.

\section{B. Kompetensi Individu}

PT. Perkebunan Sumatera Utara berusaha mendapatkan pegawai yang kompeten dan profesional di bidangnya masing-masing melalui proses seleksi yang efektif sesuai spesifikasi jabatan yang ditetapkan. Setelah calon pegawai diseleksi, kemudian diberikan training selama tiga bulan untuk mengetahui apakah calon pegawai tersebut mampu mengerjakan tugas-tugas yang dibebankan atau tidak. Jika calon pegawai mampu mengerjakan tugas-tugas yang dibebankan selama training, dan dinilai memenuhi spesifikasi jabatan yang ditetapkan, kemudian ditempatkan pada posisi yang lowong. Kompetsni pegawäi dilihat dari pendidikan menunjukkan bahwa yang berpendidikan SMP sebanyak 8 persen, SMU/sederajat sebanyak 46 persen, Diploma (D-III) sebanyak 20 persen dan pegawai yang berpendidikan Sarjana (S1) sebanyak 25 persen. Dengan demikian, mayoritas pegawai perusahaan berpendidikan SMU/sederajat.

Dari masa kerja pegawai menunjukkan bahwa masa kerjanya antara $0-5$ tahun sebanyak 32 pesen, antara 6 - 10 tahun sebanyak 14 persen, antara 11 - 15 tahun sebanyak 37 persen, antara 16 - 20 tahun sebanyak 12 persen dan pegawai yang masa kerjanya di atas 20 tahun sebanyak 5 persen. Dengan demikian, mayoritas pegawai perusahaan berpengalaman kerja antara 11 - 15 tahun.

\section{Kinerja Pegawai}

Kinerja pegawai merupakan kuantitas hasil kerja yang dicapai pegawai selama periode tertentu. Kinerja perusahaan merupakan akumulasi dari kinerja pegawai. Persentase pencapaian anggaran penjualan minyak sawit pada tahun 2010 sebesar $105,24 \%$ dan untuk karet 102,93\%. Artinya, realisasi penjualan melebihi anggaran penjualan yang ditetapkan. Pada tahun 2011, persentase pencapaian anggaran penjualan minyak sawit sebesar 94,35\% dan karet sebesar 96,31\%. Pada tahun 2012, persentase pencapaian anggaran penjualan minyak sawit sebesar 91,09\% dan karet sebesar $88,80 \%$. Pada tahun 2013 , persentase pencapaian anggaran penjualan minyak 
sawit sebesar $89,76 \%$ dan karet sebesar $89,16 \%$. Dari data tersebut, terlihat bahwa anggaran penjualan minyak sawit dan karet tahun 2011-2013 tidak tercapai. Tidak tercapainya kinerja pegawai pada tahun 2013 salah satu disebabkan oleh lingkungan kerja dan kompetensi individu kurang dipertimbangkan oleh atasan dalam menempatkan pegawai.

\section{Hasil Uji Validitas dan Reliabilitas}

Berdasarkan hasil uji validitas diketahui nilai cronbach's alpha sebesar 0,966. Artinya kedua puluh enam indikator pengukuran variabel penelitian (lingkungan kerja, kompetensi individu dan kinerja pegawai) sudah reliabel. Hasil uji reliabilitas variabel lingkungan kerja, kompetensi individu dan kinerja pegawai sudah valid, karena cronbach's alpha if item $>0,50$.

\section{E. Hasil Uji Asumsi Klasik}

Hasil uji normalitas dari Tabel 1 di bawah ini nampak bahwa Nilai KolmogorovSminorv (K-S) untuk variabel lingkungan kerja $\left(\mathrm{X}_{1}\right)$ sebesar 1,208 dengan tingkat signifikan 0,108 lebih besar dari 0,05. Artinya, variabel lingkungan kerja terdistribusi normal dan Nilai Kolmogorov-Sminorv (K-S) untuk variabel kompetensi individu $\left(\mathrm{X}_{2}\right)$ sebesar 0,778 dengan tingkat signifikan 0,580 lebih besar dari 0,05. Artinya, variabel kompetensi individu terdistribusi normal.

Tabel 1. One-Sample Kolmogorov-Smirnov Test

\begin{tabular}{|c|c|c|c|}
\hline & & X1 & $\mathrm{X} 2$ \\
\hline \multicolumn{2}{|c|}{$\bar{N}$} & 43 & 43 \\
\hline \multirow{2}{*}{$\begin{array}{c}\text { Normal } \\
\text { Parameters }(a, b)\end{array}$} & Mean & 3,4472 & 3,3465 \\
\hline & Std. Deviation & 0,56831 & 0,57128 \\
\hline \multirow{3}{*}{$\begin{array}{l}\text { Most Extreme } \\
\text { Differences }\end{array}$} & Absolute & 0,184 & 0,119 \\
\hline & Positive & 0,092 & 0,082 \\
\hline & Negative & $-0,184$ & $-0,119$ \\
\hline \multicolumn{2}{|c|}{ Kolmogorov-Smirnov Z } & 1,208 & 0,778 \\
\hline \multicolumn{2}{|c|}{ Asymp. Sig. (2-tailed) } & 0,108 & 0,580 \\
\hline
\end{tabular}

a Test distribution is Normal.

$b$ Calculated from data.

Tabel 2 Hasil Uji Multikolinieritas

\begin{tabular}{|c|c|c|}
\hline \multirow{2}{*}{ Model } & \multicolumn{2}{|c|}{ Collinearity Statistics } \\
\cline { 2 - 3 } & Tolerance & VIF \\
\hline X1 & 0,250 & 3,999 \\
X2 & 0,250 & 3,999 \\
\hline
\end{tabular}

Sumber: Data Diolah dari Hasil Penelitian, 2017 
Dari tabel 2 di atas nampak bahwa nilai VIF sebesar 3,999 dan 3,999. Dengan demikian, dapat dikatakan bahwa lingkungan kerja dan kompetensi individu tidak mengalami multikolinieritas, karena nilai VIF lebih kecil dari 10.

Scatterplot

Dependent Variable: $Y$

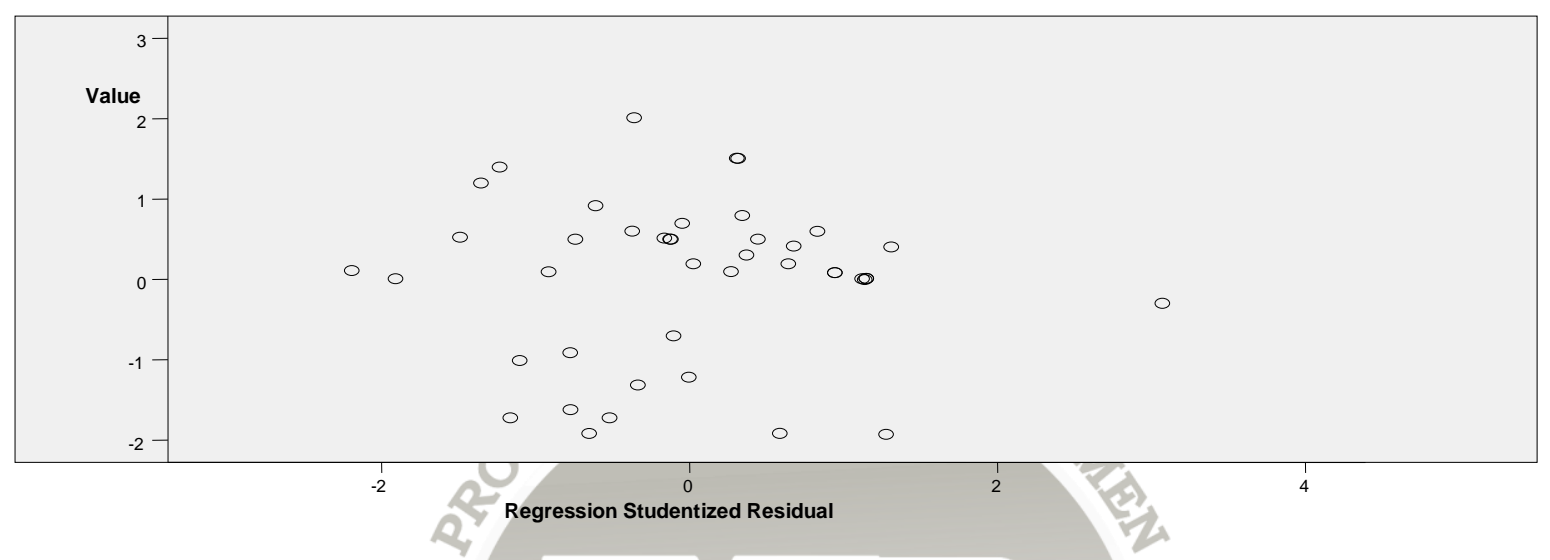

Gambar 2 Hasil Uji Heteroskedastisitas

Sumber: Hasil Penelitian, data diolah (2014)

Dari gambar 2 diketahui bahwa titik-titk menyebar secara tidak teratur (pola tidak jelas) di atas dan di bawah angka nol pada sumbu $Y$, artinya tidak terjadi heteroskedastisitas.

\section{F. Pengujian Hipotesis}

Berdasarkan hasil uji $\mathrm{F}$ diperoleh hasilnya pada tabel berikut:

Tabel 3 Anova(b)

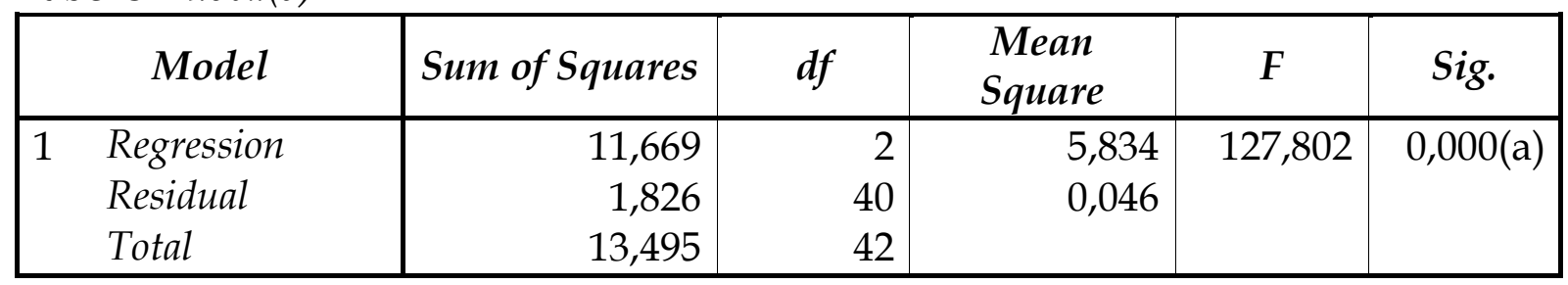

a Predictors: (Constant), $\mathrm{X} 2, \mathrm{X} 1$

b Dependent Variable: $\mathrm{Y}$

Sumber: Data Diolah dari Hasil Penelitian, 2017


tingkat signifikansi sebesar 0,000, artinya, lingkungan kerja dan kompetensi individu berpengaruh secara simultan terhadap kinerja pegawai pada PT. Perkebunan Sumatera Utara. Dengan demikian, hipotesis diterima. Hasil uji t disajikan pada tabel 4 berikut: 
Tabel 4 Coefficients(a)

\begin{tabular}{|c|c|c|c|c|c|c|}
\hline & \multirow[t]{2}{*}{ Model } & \multicolumn{2}{|c|}{$\begin{array}{l}\text { Unstandardized } \\
\text { Coefficients }\end{array}$} & \multirow{2}{*}{$\begin{array}{c}\text { Standardized } \\
\text { Coefficients } \\
\text { Beta }\end{array}$} & \multirow[t]{2}{*}{$t$} & \multirow[t]{2}{*}{ Sig. } \\
\hline & & $B$ & Std. Error & & & \\
\hline \multirow[t]{3}{*}{1} & (Constant) & 0,145 & 0,207 & & $\begin{array}{r}0,70 \\
0\end{array}$ & 0,488 \\
\hline & X1 & 0,440 & 0,116 & 0,441 & $\begin{array}{r}3,79 \\
5\end{array}$ & 0,000 \\
\hline & $\mathrm{X} 2$ & 0,517 & 0,115 & 0,521 & $\begin{array}{r}4,48 \\
0\end{array}$ & 0,000 \\
\hline
\end{tabular}

a Dependent Variable: $Y$

Sumber: Data Diolah dari Hasil Penelitian, 2017

Berdasarkan tabel 2 di atas nampak bahwa thitung sebesar 3,795 dan 4,480 dengan tingkat signifikansi sebesar 0,000 artinya, lingkungan kerja dan kompetensi berpengaruh secara parsial terhadap kinerja pegawai pada PT. Perkebunan Sumatera Utara. Dengan demikian hipotesis diterima.

\section{G. Pengaruh Lingkungan Kerja dan Kompetensi Individu Terhadap Kinerja Pegawai}

Nilai koefisien determinan ( $R$ Square) diperoleh hasil pengujian sebagai berikut:

Tabel 5 Model Summary(b)

\begin{tabular}{|c|r|r|r|r|}
\hline Model & $R$ & $R$ Square & Adjusted R Square & $\begin{array}{c}\text { Std. Error of the } \\
\text { Estimate }\end{array}$ \\
\hline 1 & $0,930(\mathrm{a})$ & 0,865 & 0,858 & 0,21366 \\
\hline
\end{tabular}

a Predictors: (Constant), X2, X1

b Dependent Variable: Y

Sumber: Data Diolah dari Hasil Penelitian, 2017

Berdasarkan tabel 5 di atas, diketahui ( $R$ Square) sebesar 0,865. artinya, kinerja pegawai dapat dijelaskan oleh lingkungan kerja dan kompetensi individu sebesar $86,5 \%$ sedangkan $13,5 \%$ dijelaskan oleh faktor lain, seperti pemberian penghargaan dan kepemimpinan. Dilihat dari nilai koefisien regresinya diketahui bahwa pengaruh lingkungan kerja terhadap kinerja pegawai sebesar 0,440. Artinya, jika lingkungan kerja berubah, maka kinerja pegawai akan berubah sebesar 0,440. Dengan demikian, terdapat pengaruh positif antara lingkungan kerja terhadap kinerja pegawai. Hasil penelitian ini sesuai dengan penelitian Presilia dan Octavia (2008) dan Linawati dan Suhaji (2012).

Dilihat dari nilai koefisien regresinya diketahui bahwa pengaruh kompetensi individu terhadap kinerja pegawai sebesar 0,517. Artinya, jika kompetensi individu berubah, maka kinerja pegawai akan berubah sebesar 0,517. Dengan demikian, terdapat pengaruh positif antara kompetensi individu terhadap kinerja pegawai. Hasil penelitian ini sesuai dengan penelitian Rizal, dkk., (2013), Febriyanti dkk., (2013), serta penelitian Linawati dan Suhaji (2012). 


\section{KESIMPULAN}

Variasi kinerja pegawai dapat dijelaskan oleh lingkungan kerja dan kompetensi individu sebesar 86,5 persen. Lingkungan kerja dan kompetensi individu berpengaruh positif dan signifikan secara simultan dan secara parsial terhadap kinerja pegawai pada PT. Perkebunan Sumatera Utara. Saran yang diberikan sebagai bahan pertimbangan kepada pimpinan perusahaan adalah: Untuk meningkatkan kinerja pegawai, sebaiknya perusahaan memperbaiki lingkungan kerja agar pegawai lebih berkonsentrasi dalam mengerjakan tugas-tugasnya dan meningkatkan kompetensi individu dengan memiliki program diklat yang terprogram dan sesuai dengan tuntutan pekerjaan pegawai, sehingga kinerja pegawai dapat ditingkatkan.

\section{DAFTAR PUSTAKA}

Astuti, Sri Endah Budi. 2009. Risiko Pekerjaan Terhadap Musculoskeletal Disoders (MSDs). Artikel FKM Universitas Indonesia.

Febriyanti, Anggita Ria; Utami, Hamidah Nayati dan Hakam, Mochammad Soe'oed. 2013. Pengaruh Pelatihan Terhadap Kompetensi dan Kinerja Karyawan Pada PT. Perkebunan Nusantara X (Persero) PG. Lestari Ngajuk. Artikel: Fakultas Ilmu Administrasi Universitas Brawijaya.

Hasibuan, Malayu. 2005. Manajemen Sumber Daya Manusia. Edisi Revisi, Cetakan Keenam, Jakarta: Bumi Aksara.

Husien, Nirza Marzuki dan Hadi, Andrian. 2012. Pengaruh Lingkungan Kerja dan Karakteristik Individu Terhadap Kepuasan Kerja Pegawai. April 2012, Vol. 13, Nomor 1.

Linawati dan Suhaji. 2012. Pengaruh Motivasi, Kompetensi, Kepemimpinan, dan Lingkungan Kerja Terhadap Kinerja Karyawan (Studi Pada PT. Herculon Carpet Semarang). Artikel: Sekolah Tinggi Ilmu Ekonomi Widya Manggala, Email: Lina_watiii@yahoo.co.id.

Mangkunegara, Anwar Prabu. 2005. Evaluasi Kinerja SDM. Cetaka Pertama, Bandung: Refika Aditama.

Presilia dan Octavia, Regina Fortunata. 2010. Analisis Pengaruh Lingkungan Kerja, Karakteristik Individu, dan Motivasi Terhadap Kinerja Pegawai (Kasus: PT. Megatama Plasindo). Jurnal: Bisnis dan Ekonomi, Binus University, DKI Jakarta, Indonesia.

Riani, Asri Laksmi. 2011. Budaya Organisasi. Edisi Pertama, Cetakan Pertama, Yogyakarta: Graha Ilmu.

Rizal, Yosef; Musa Hubeis; Syafri Mangkuprawira, dan Agus Maulana. 2013. Pengaruh Faktor Kompetensi Terhadap Kinerja Individu di Perusahaan Agro Industri yang Go Public di Bursa Efek Indonesia, Jurnal IKM, Vol.8 No. 1, Februari 2013.

Simanjuntak, Payaman. 2005. Manajemen dan Evaluasi Kinerja. Edisi Pertama, Cetakan Pertama, Jakarta: Lembaga Penerbit FEUI.

Sugiyono. 2008. Metode Penelitian Bisnis. Cetakan Keenam, Bandung: Alfabeta.

Sutrisno, Edy. 2009. Manajemen Sumber Daya Manusia. Edisi Pertama, Cetakan Pertama, Jakarta: PT. Prenada Media Group.

Tohardi, Ahmad. 2006. Manajemen Sumber Daya Manusia. Bandung: CV. Mandar Maju. 